\title{
Multitarget Therapy: An Effective and Safe Therapeutic Regimen for Lupus Nephritis
}

\author{
Tianbiao Zhou ${ }^{1, *}$, Xialan Zhang ${ }^{2, *}$, Wenshan $\operatorname{Lin}^{1}$, Shujun $\operatorname{Lin}^{1}$ \\ ${ }^{1}$ Department of Nephrology, the Second Affiliated Hospital, Shantou University Medical College, 515041, Shantou, \\ Guangdong, China. ${ }^{2}$ Department of Obestetrics and Gynecology, the Second Affiliated Hospital, Shantou University \\ Medical College, 515041, Shantou, Guangdong, China
}

Received, August 3, 2019; Revised, September 22, 2019; Accepted, October 3, 2019; Published, October 3, 2019.

\begin{abstract}
Introduction: We evaluated the effectiveness and safety of various multitarget therapies for inducing remission in lupus nephritis patients. Methods: Randomized controlled trials (RCT) were identified and extracted from the Embase, PubMed, Chinese Biomedical Literature Database (CBM), and the Cochrane Library until Oct 31,2018, investigations meeting inclusion criteria were extracted, and data were analyzed by meta-analysis. The total remission (TR; complete to partial remission), complete remission (CR), albumin, proteinuria levels, negative rate of anti-double-stranded DNA antibody (ds-DNA), negative rate of anti-nuclear antibody (ANA), and systemic lupus erythematosus disease activity index (SLE-DAI) were calculated using the software of RevMan 5.3. Results: Eleven RCTs were included and analyzed. The multitarget therapy group exhibited a higher value of $\mathrm{CR}(\mathrm{OR}=3.06,95 \% \mathrm{CI}$ : 2.35-3.99, $\mathrm{P}<0.00001)$ as well as TR $(\mathrm{OR}=3.83$, 95\%CI: 2.77-5.31, $\mathrm{P}<0.00001)$ than those in the cyclophosphamide $(\mathrm{CYC})$ group. In addition, multitarget therapies had more albumin $(\mathrm{WMD}=3.50,95 \% \mathrm{CI}$ : $1.04-5.95, \mathrm{P}=0.005)$, greater albumin increases $(\mathrm{OR}=1.96$, 95\%CI: $0.63-3.29, \mathrm{P}=0.004)$ and higher negative rates of ds-DNA (OR=2.13, 95\%CI: $1.51-3.01, \mathrm{P}<0.0001)$ and ANA (OR=2.82, 95\%CI: $1.77-4.50, \mathrm{P}<0.0001)$ when compared with the CYC group. This group also had less proteinuria levels (WMD $=-0.55,95 \% \mathrm{CI}$ : -0.79 to $-0.30, \mathrm{P}<0.0001$ ), lower degrees of SLE-DAI ( $\mathrm{OR}=-1.80,95 \% \mathrm{CI}:-2.78$ to $-0.81, \mathrm{P}=0.0004)$, and a lower adverse reaction rate. For example, gastrointestinal syndrome, irregular menstruation and leucopenia happened less frequently in the multitarget therapy group. However, hypertension was more prevalent in the multitarget therapy group. Conclusions: Multitarget therapy is an effective and safe intervention for inducing remission in lupus nephritis patients.
\end{abstract}

\section{INTRODUCTION}

Lupus nephritis (LN) is the most frequent major complication in patients with systemic lupus erythematosus (SLE), and the morbidity is approximately $30 \%-50 \%$ in SLE patients [1, 2]. Immune activation of B cells and T helper cells can not only play a role in the pathogenesis of SLE, but also induce the inflammation, which is associated with the onset of LN [3]. B cells are also involved in $\mathrm{T}$ cell activation and cytokine production [4]. Persistent inflammation may induce permanent damage in the glomerulus and kidney tubules, resulting in chronic kidney disease. Without intervention, LN can develop into end stage renal disease.

Glucocorticoids (GC) plus cyclophosphamide (CYC) is the traditional therapy for LN, which is used to improve long-term prognosis of patients with LN. However, severe adverse effects are associated with this treatment, including sepsis, malignancy, hemorrhagic cystitis, and amenorrhea.
In the past decades, some new immunosuppressants such as tacrolimus (TAC), cyclosporine A (CsA), mycophenolate mofetil (MMF), and leflunomide are used to treat LN.

Multitarget therapies, such as TAC plus MMF or leflunomide plus MMF, are successfully used for immunosuppression in patients with kidney transplants, and these drugs have additive inhibitory effects on lymphocytes [2]. In this study, we conducted a meta-analysis to calculate the effectiveness and safety of multitarget therapies for the induction of remission of lupus nephritis patients.

\footnotetext{
Corresponding Author: Tianbiao Zhou: Department of Nephrology, the Second Affiliated Hospital, Shantou University Medical College, 515041, No. 69 Dongsha Road, Shantou, China; E-mail: zhoutb@aliyun.com - *Principal authors.
} 


\section{MATERIALS AND METHODS}

\section{Search strategies for identified studies}

A search strategy of Cyclophosphamide, CYC, Tacrolimus, TAC, Mycophenolate mofetil, MMF, Leflunomide, LEF, systemic lupus erythematosus and lupus nephritis, were entered into Embase, PubMed, Chinese Biomedical Literature Database (CBM), and the Cochrane Library (up to Oct 31, 2018) to identify eligible studies without language limitations. Other resources such as the references cited in articles relevant to this update were also evaluated.

\section{Selection of studies}

By reviewing the titles, abstracts, and, if necessary, the full texts, two abstractors individually screened out relevant studies. Publications were included in the analysis if patients were diagnosed as lupus nephritis by renal biopsy, and the study type was limited to randomized controlled trials. Eligibility criteria required individuals to have received different types of immunosuppressants combinations as the multitarget therapies in one arm of the treatment and CYC in the other. On the contrary, retrospective studies, one-arm studies, case reports, letters, reviews, guidelines and comments were excluded from the study. Studies with unclear diagnostic criteria for lupus nephritis in the trials were also not included. Reviewers would discuss and resolve any discordant opinions. In the analysis, only those randomized controlled trials related to the multitarget therapies for $\mathrm{LN}$ were included.

\section{Outcome measures}

The primary outcomes, including the effectiveness and tolerance of multitarget therapy, were assessed. The efficacy was measured by related indices such as total remission (TR; complete remission (CR) plus partial remission (PR)), CR, rise of serum albumin, decrease of urinary protein excretion, negative rate of anti-double-stranded DNA antibody (ds-DNA) and anti-nuclear antibody (ANA), systemic lupus erythematosus disease activity index (SLE-DAI). The safety of multitarget therapies was measured by adverse reaction rate and side effects such as gastrointestinal syndrome, hypertension, hyperglycemia, leucopenia, infection of various organ systems, herpes zoster or varicella, alopecia, and irregular menstruation.

\section{STATISTICAL ANALYSIS}

Review Manager Version 5.3 software was used to pool the data extracted from the individual studies. $\mathrm{I}^{2}$ statistics was used to detect the heterogeneity. When the $p$-value $\geq 0.1$ for the heterogeneity test, a fixed effects model was chosen for a more conservative estimate. If not, a random effects model was used to pool the results. Continuous data were presented using weighted mean differences (WMDs), and the odds ratio (OR) was used to show the binary data. $95 \%$ confidence intervals $(95 \% \mathrm{CI})$ were assessed in the included studies. A value of $p<0.05$ was regarded as statistical significance.

\section{RESULTS}

\section{Search results}

There were 11 randomized controlled trials [5-15], totaling 1001 participants, of multitarget therapy for lupus nephritis in this meta-analysis, and detailed study characteristics are shown in Table 1. Of these 11 studies, $8(n=767)$ compared TAC with MMF plus GC to CYC plus GC, while $3(\mathrm{n}=234)$ compared leflunomide plus MMF with or without GC to CYC with or without GC. The patients had a diagnosis of class II, III, IV, V, III+V or IV+V LN according to the ISN/RPS 2003 classification of LN.

\section{Efficacy}

\section{Multitarget therapies versus CYC}

To detect the efficacy of multitarget therapies in lupus nephritis patients, data from 11 studies [5-15] $(\mathrm{n}=1001)$ was used to compare multitarget therapies plus GC with CYC plus GC. Overall, there was a significant improvement in $\mathrm{CR}(\mathrm{P}<$ 0.00001, OR=3.06, 95\%CI: 2.35-3.99; Table 2 and Figure 1), TR $(\mathrm{P}<0.00001, \mathrm{OR}=3.83,95 \% \mathrm{CI}$ : 2.77-5.31; Table 2 and Figure 2), albumin $(\mathrm{P}=0.005, \mathrm{WMD}=3.50,95 \% \mathrm{CI}: 1.04-5.95$; Table $2)$, albumin increase level $(\mathrm{P}=0.004, \mathrm{OR}=1.96$, 95\%CI: 0.63-3.29; Table 2), negative rate of dsDNA ( $\mathrm{P}<0.0001, \mathrm{OR}=2.13,95 \% \mathrm{CI}$ : 1.51-3.01; Table 2 and Figure 3), negative rate of ANA (P < $0.0001, \mathrm{OR}=2.82,95 \% \mathrm{CI}: 1.77-4.50$; Table 2 and Figure 4) and a significant reduction in proteinuria levels $(\mathrm{P}<0.0001, \mathrm{WMD}=-0.55,95 \% \mathrm{CI}:-0.79$ to -0.30 ; Table 2), SLE-DAI ( $\mathrm{P}=0.0004, \mathrm{OR}=-1.80$, 95\%CI:-2.78 to -0.81 ; Figure 5 and Table 2) in favor of multitarget therapy. 


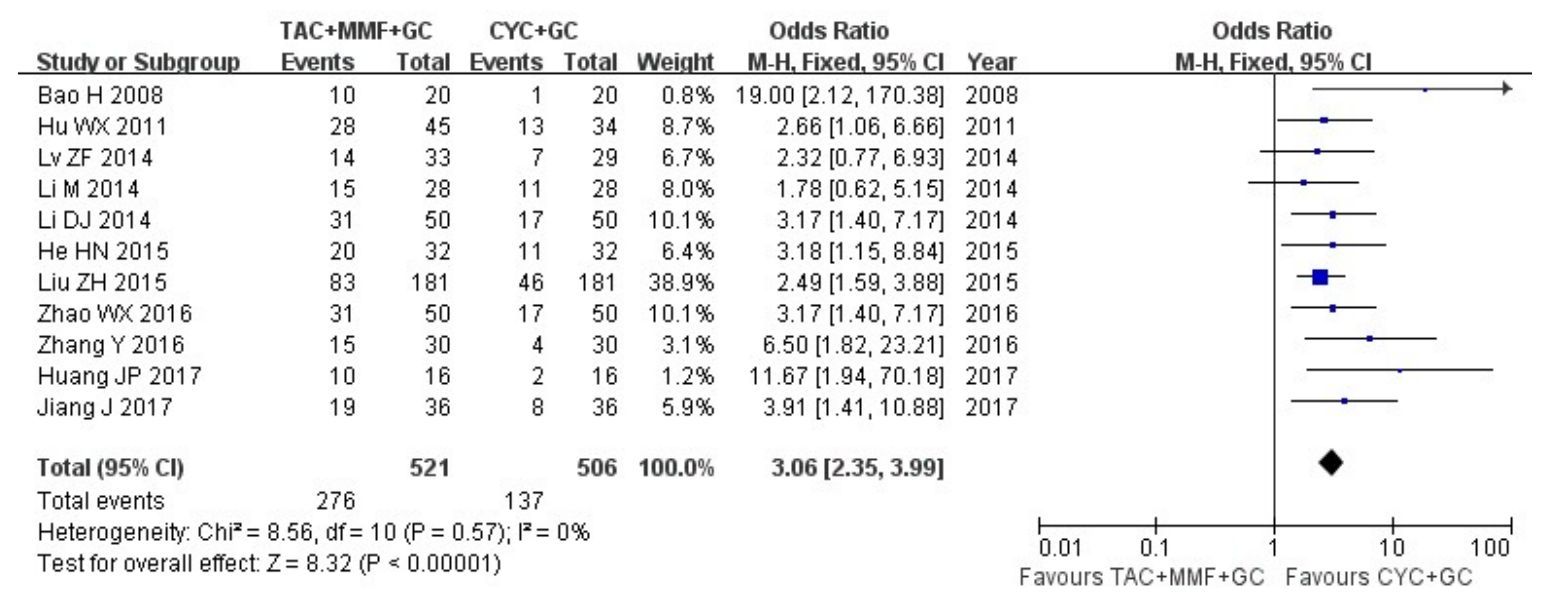

Figure 1. Assessment of the efficacy of multitarget therapy for lupus nephritis with regards to complete remission (CR).

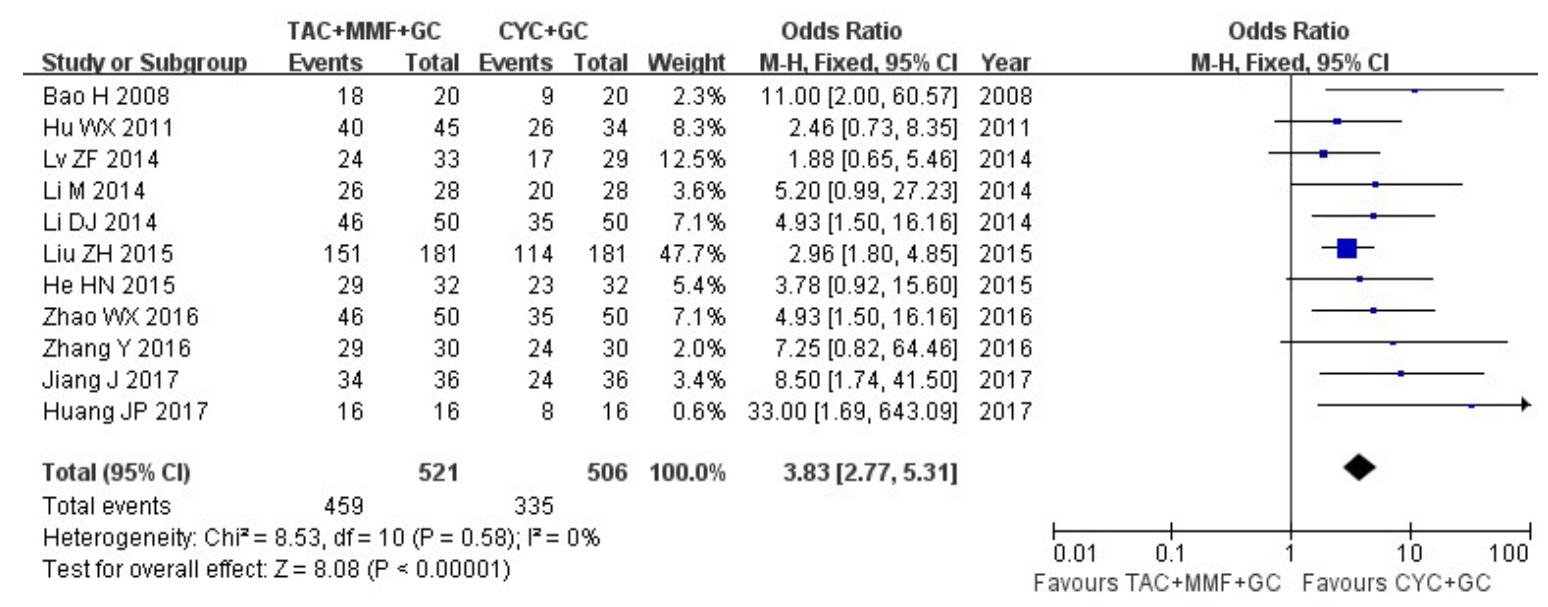

Figure 2. Assessment of the efficacy of multitarget therapy for lupus nephritis with regards to total remission (complete or partial remission) (TR).

\section{TAC plus MMF versus CYC}

Regarding the TAC+MMF vs. CYC, eight studies [5-12] including 767 patients were analyzed to determine the efficacy of TAC+MMF. TAC + MMF was superior to $\mathrm{CYC}$ in $\mathrm{CR}(\mathrm{P}<0.00001, \mathrm{OR}=3.10$, 95\%CI: 2.30-4.19; Table 2), TR (P < 0.00001, $\mathrm{OR}=4.06,95 \% \mathrm{CI}: 2.80-5.89$; Table 2), albumin (P $<0.00001$, WMD $=5.21,95 \%$ CI: 3.44-6.98; Table 2), albumin increase level $(\mathrm{P}=0.004, \mathrm{OR}=1.96$, 95\%CI: 0.63-3.29; Table 2), negative rate of dsDNA ( $\mathrm{P}=0.0004, \mathrm{OR}=2.09$, 95\%CI: 1.39-3.15; Table 2), negative rate of ANA ( $\mathrm{P}=0.0005$, $\mathrm{OR}=3.40, \quad 95 \% \mathrm{CI}:$ 1.72-6.74; Table 2) and decreasing proteinuria levels $(\mathrm{P}<0.00001$, $\mathrm{WMD}=-0.61,95 \% \mathrm{CI}$ : -0.76 to -0.45 ; Table 2$)$ and SLE-DAI $(\mathrm{P}<0.00001, \mathrm{OR}=-1.91,95 \% \mathrm{CI}:-2.51$ to -1.30; Table 2). This result was in accordance with the overall effect of multitarget therapies compared to CYC.

\section{Leflunomide plus MMF versus CYC}

Three papers [13-15] that included 234 lupus nephritis patients were analyzed to assess the effectiveness of leflunomide $+\mathrm{MMF}$. Compared with CYC, leflunomide+MMF was more effective in $\mathrm{CR}(\mathrm{P}=0.0001, \mathrm{OR}=2.93,95 \% \mathrm{CI}$ : $1.69-5.08$; 
Table 2$)$ and $\mathrm{TR}(\mathrm{P}=0.0009, \mathrm{OR}=3.16,95 \% \mathrm{CI}$ : 1.60-6.23; Table 2). Significant differences were also observed in the reduction of proteinuria levels $(\mathrm{P}=0.02, \mathrm{WMD}=-0.48,95 \% \mathrm{CI}$ : -0.87 to -0.09 ; Table 2), negative rate of ds-DNA ( $\mathrm{P}=0.02$, $\mathrm{OR}=2.22$, 95\%CI: 1.16-4.26; Table 2) and ANA $(\mathrm{P}=0.007, \mathrm{OR}=2.39,95 \% \mathrm{CI}: 1.26-4.53$; Table 2$)$. However, leflunomide+MMF had similar effects to those of the CYC group on albumin $(\mathrm{P}=0.08$, $\mathrm{WMD}=1.87$, 95\%CI: -0.24-3.98; Table 2) and SLE-DAI $(\mathrm{P}=0.0007, \mathrm{OR}=-2.00,95 \% \mathrm{CI}:-3.1$ to 0.85 ; Table 2).

\section{Safety}

\section{Multitarget therapies versus CYC}

Compared with CYC group, the multitarget therapy group had a lower rate of adverse reactions
( $\mathrm{P}=0.02, \mathrm{OR}=0.28,95 \% \mathrm{CI}: 0.01-0.81$; Table 3$)$, indicating enhanced tolerability. Specifically, the incidence rates of gastrointestinal syndrome $(\mathrm{P}=0.01, \mathrm{OR}=0.35,95 \%$ CI: $0.15-0.80$; Table 3$)$, leucopenia $(\mathrm{P}=0.0009, \mathrm{OR}=0.38,95 \% \mathrm{CI}: 0.22$ 0.67 ; Table 3), irregular menstruation $(\mathrm{P}=0.01$, $\mathrm{OR}=0.42$, 95\%CI: 0.22-0.81; Table 3) were lower in the multitarget therapy group. However, the incidence rate of hypertension in multitarget therapy group was greater than that in the CYC group. This study did not find a significant difference among the incidence rates of hyperglycemia, pneumonia, skin infection, urinary tract infection, upper respiratory infection, herpes zoster or varicella, or alopecia between the two groups (Table 3 ).

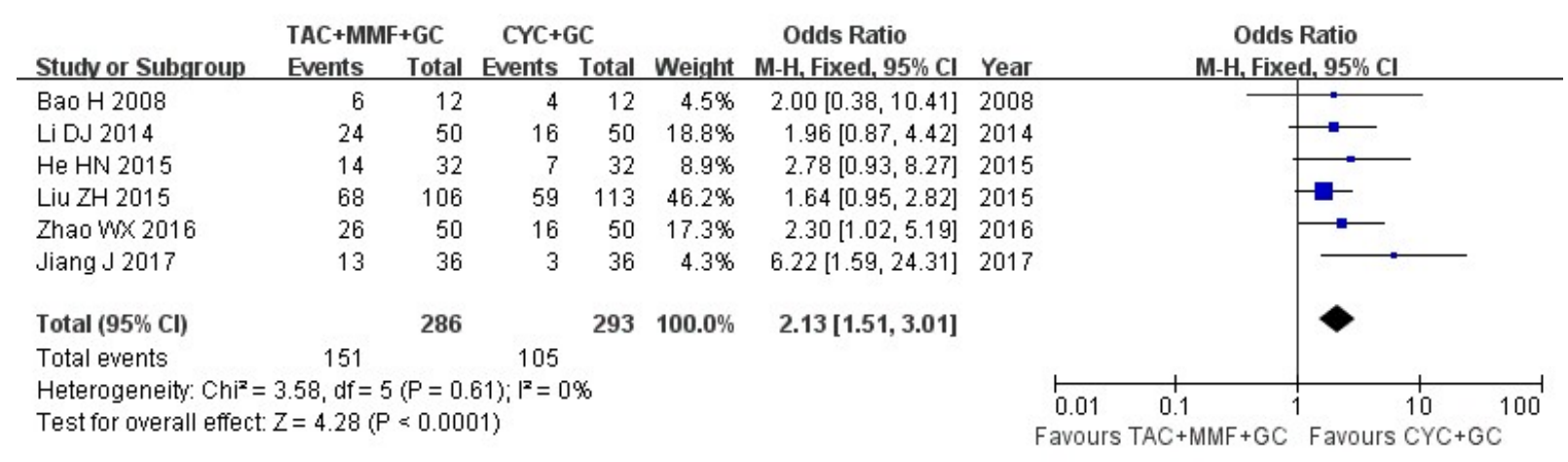

Figure 3. Assessment of the efficacy of multitarget therapy for lupus nephritis with regards to negative rates of antidouble-stranded DNA antibody (ds-DNA)

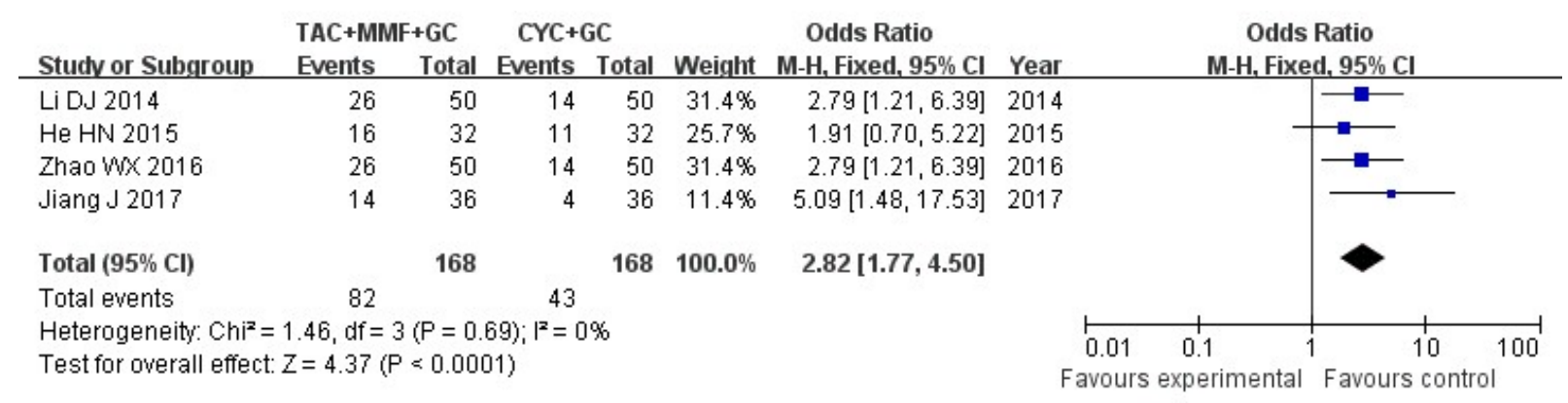

Figure 4. Assessment of the efficacy of multitarget therapy for lupus nephritis with regards to the negative rates of antinuclear antibody (ANA). 


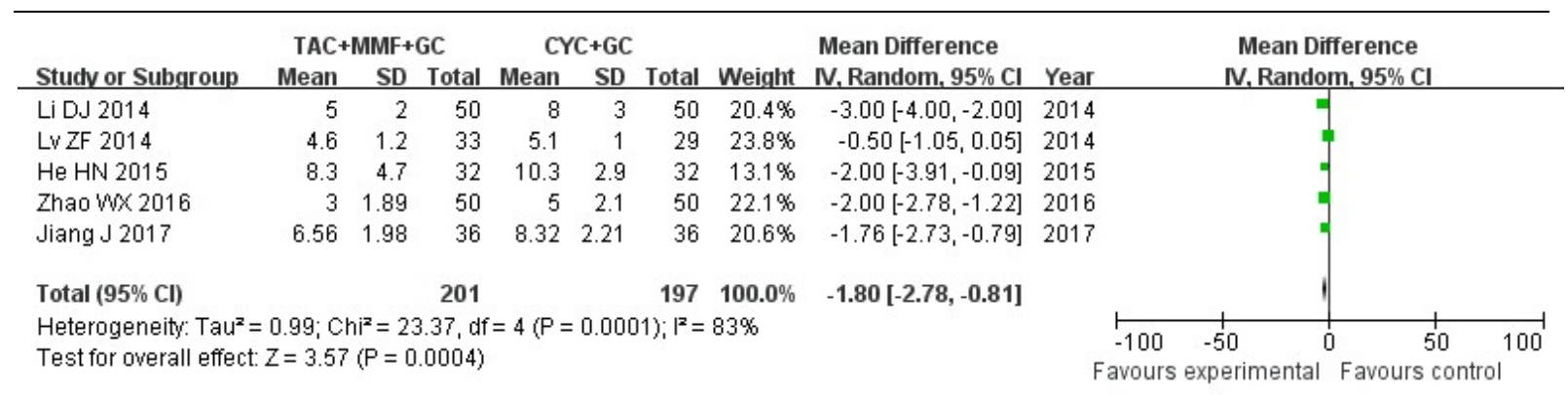

Figure 5. Assessment of the efficacy of multitarget therapy for lupus nephritis with regards to the systemic lupus erythematosus disease activity index (SLE-DAI).

\section{DISCUSSION}

In this meta-analysis, we assessed the effectiveness and safety of multitarget therapies in inducing remission in lupus nephritis patients. The results indicate that multitarget therapies can result in superior rates of TR, and CR, decreased rates of dsDNA and ANA, and low proteinuria levels. The safety of multitarget therapy was also assessed, and the results indicated that the multitarget therapy group exhibited lower adverse reaction rates than that the CYC group. Adverse events including leucopenia, gastrointestinal syndrome and irregular menstruation were less prevalent in the multitarget therapy group. These results indicate that multitarget therapy is an effective and safe treatment for lupus nephritis patients.

In the sub-group analysis, the multitarget therapy regimen of $\mathrm{TAC}+\mathrm{MMF}$ had greater values for TR, CR, albumin, and albumin increase, and decreased levels of ds-DNA, ANA, proteinuria and SLE-DAI compared to CYC. There were eight RCTs included for this meta-analysis. Furthermore, the comparison of the multitarget therapy regimen of leflunomide +MMF with CYC indicated that the multitarget therapy group had greater of TR and $\mathrm{CR}$, and decreased levels of ds-DNA, ANA, proteinuria. There were only three RCTs included for this meta-analysis, and additional studies are needed to confirm these findings.

In a previous study, Deng et al [16] performed a meta-analysis and reported that multitarget therapy is more effective at inducing CR compared with CYC, and the rates of irregular menstruation, leukopenia, gastrointestinal symptoms and were significantly reduced in the multitarget therapy group compared with the CYC group. However, the multitarget therapy group exhibited a higher prevalence of new-onset hypertension than the
CYC group. Our meta-analysis had similar results, and we also included a meta-analysis of leflunomide $+\mathrm{MMF}$ vs. CYC.

In the current meta-analysis, the results indicate that multitarget therapy is a valid therapeutic option for inducing remission in lupus nephritis patients. Additional RCTs are needed to confirm the effectiveness and safety of multitarget therapies for $\mathrm{LN}$.

\section{REFERENCES}

1. Ichinose K, Kitamura M, Sato S, Eguchi M, Okamoto M, Endo Y, Tsuji S, Takatani A, Shimizu $\mathrm{T}$, Umeda $\mathrm{M}$ et al: Complete renal response at 12 months after induction therapy is associated with renal relapse-free rate in lupus nephritis: a singlecenter, retrospective cohort study. Lupus 2019:961203319829827. doi: 10.1177/0961203319829827.

2. Jesus D, Rodrigues M, da Silva JAP, Ines L: Multitarget therapy of mycophenolate mofetil and cyclosporine $\mathrm{A}$ for induction treatment of refractory lupus nephritis. Lupus 2018, 27(8):1358-1362. doi: 10.1177/0961203318758508.

3. Cogollo E, Silva MA, Isenberg D: Profile of atacicept and its potential in the treatment of systemic lupus erythematosus. Drug design, development and therapy 2015, 9:1331-1339. doi: 10.2147/DDDT.S71276.

4. Schwartz N, Goilav B, Putterman C: The pathogenesis, diagnosis and treatment of lupus nephritis. Current opinion in rheumatology 2014, 26(5):502-509. doi: 10.1097/BOR.0000000000000089.

5. Bao H, Liu ZH, Xie HL, Hu WX, Zhang HT, Li LS: Successful treatment of class V+IV lupus nephritis with multitarget therapy. Journal of the American Society of Nephrology : JASN 2008, 19(10):2001- 
2010. doi: 10.1681/ASN.2007121272.

6. Hu W, Chen Y, Liu Z, Zhang H, Chen H, Zeng C, Zhang L, Liu Z: A prospective clinical trial of corticosteroids in combination with mycophenolate mofetil dispersible tablets and tacrolimus for the induction treatment of lupus nephritis. Chin Nephrol Dail Transplant 2011, 20(4):301-306. [In Chinese]

7. Huang J, Yu Y, Gao W, Chen W, Hua D, Wu Y, Jiang J: Clinical study on the efficacy and safety of treatment of both proliferative and membranous lupus nephritis with multitarget therapy. Chin Clin Nephrol 2017, 17(2):100-104. [In Chinese]

8. Jiang J, Guo Q, Duan R: Effects of mycophenolate mofetil combined with tacrolimus on immunological indexes and activity index of patients with lupus nephritis. Journal of Clinical and Experimental Medicine 2017, 16(4):367-370. [In Chinese]

9. Li M: Efficacy and safety of corticosteroids in combination with mycophenolate mofetil dispersible tablets and tacrolimus for the induction treatment of lupus nephritis. Chinese Journal of Clinical Rational Drug Use 2014, 7(10):51-52.[In Chinese]

10. Liu Z, Zhang H, Liu Z, Xing C, Fu P, Ni Z, Chen J, Lin H, Liu F, He Y et al: Multitarget therapy for induction treatment of lupus nephritis: a randomized trial. Annals of internal medicine 2015, 162(1):18-26. doi: 10.7326/M14-1030.
11. Zhang $\mathrm{Y}$, Lin S, Chen D, Liang J: Clinical therapeutic effects of multi-target treatment on type-IV lupus nephritis and the effects on serum IL6, IL-13, and IL-18 levels. Chin Clin Nephrol 2016, 16(1):8-11. [In Chinese]

12. Zhao W, Xu H: Clinical efficacy and safety of lupus nephritis with multi-target therapy. Journal of Hebei Medical University in Chinese 2016, 37(1):61-63. [In Chinese]

13. He N: Comparison of eficacy and safety of leflunomide combined with mycophenolate mofetil and cyclophosphamide in patients with lupus nephritis. International Joumal of Urology and Nephrology 2015, 35(5):739-743. [In Chinese]

14. Li D, Li Y, Che H: Effect of leflunomide combined with mycophenolate mofetil on patients with lupusnephritis. Chin $J$ Clinicians(Electronic Edition) 2014, 8(5):853-857. [In Chinese]

15. Lv Z, Zhuang Y, Chen Y, Wang Z, Tan Z: Clinical efficacy of multi-target induction therapy with mycophenolate mofetil and leflunomide on lupus nephritis. Chin J Biomed Eng 2014, 20(6):413-417. [In Chinese]

16. Deng J, Luo L, Zhu L, Xie H, xie H: Multitarget therapy versus intravenous cyclophosphamide in the induction treatment of lupus nephritis: a metaanalysis of randomized controlled trials. Turkish journal of medical sciences 2018, 48(5):901-910. doi: 10.3906/sag-1804-57. 
J Pharm Pharm Sci (www.cspsCanada.org) 22, 365 - 375, 2019

Table 1. Characteristics of the studies included in this meta-analysis.

\begin{tabular}{|c|c|c|c|c|c|c|}
\hline Ref & Design & Treatment & Details & Patients & Main outcome & Adverse events \\
\hline 5 & $\begin{array}{l}\text { Multicenter,randomized, } \\
\text { open-label, clinical trial }\end{array}$ & $\begin{array}{l}\mathrm{TAC}+\mathrm{MMF}+\mathrm{GC} \\
\text { vs } \mathrm{CYC}+\mathrm{GC}\end{array}$ & $\begin{array}{l}\text { M: TAC } 3-4 \mathrm{mg} / \text { day; TAC blood concentration within } 5-7 \mathrm{ng} / \mathrm{m} \text {; } \\
\text { MMF } 0.75-1 \mathrm{~g} / \text { day; MPA AUC }(0-12 \mathrm{~h}), 20-45 \mathrm{mg} \mathrm{h} / \mathrm{L} \text {. C: IVC } \\
0.5-1 \mathrm{~g} / \mathrm{m}^{2} \text { per month for } 6-9 \text { months. All MP pulse therapy } \\
\text { followed by oral prednisone }\end{array}$ & 12- $60 \mathrm{yr}$; Class V+IV LN & $\begin{array}{l}\mathrm{CR} \text {, TR, urinary protein decline, } \\
\text { rise of serum albumin, negative rate } \\
\text { of ds-DNA }\end{array}$ & $\begin{array}{l}\text { Gastrointestinal syndrome, leucopenia, } \\
\text { hypertension, hyperglycemia, upper } \\
\text { respiratory infection, pneumonia, herpes } \\
\text { zoster or varicella, urinary tract infection, } \\
\text { alopecia, irregular menstruation }\end{array}$ \\
\hline 10 & $\begin{array}{l}\text { Multicenter,randomized, } \\
\text { open-label, clinical trial }\end{array}$ & $\begin{array}{l}\mathrm{TAC}+\mathrm{MMF}+\mathrm{GC} \\
\text { vs } \mathrm{CYC}+\mathrm{GC}\end{array}$ & $\begin{array}{l}\text { M: TAC } 4 \mathrm{mg} / \text { day, MMF } 1 \mathrm{~g} / \text { day C: IVC } 0.5-1 \mathrm{~g} / \mathrm{m}^{2} \text { monthly for } \\
24 \text { weeks. All MP pulse therapy followed by oral prednisone }\end{array}$ & $\begin{array}{l}\text { 18-65 yr biopsy-proven LN } \\
\text { diagnosed within } 6 \text { months } \\
\text { before enrollment; had a } \\
\text { diagnosis of class III, IV, } \\
\text { V, III+V or IV+V LN }\end{array}$ & $\begin{array}{l}\mathrm{CR} \text {, TR, urinary protein decline, } \\
\text { rise of serum albumin, negative rate } \\
\text { of ds-DNA }\end{array}$ & $\begin{array}{l}\text { Gastrointestinal syndrome, leucopenia, } \\
\text { hypertension, hyperglycemia, upper } \\
\text { respiratory infection, pneumonia, herpes } \\
\text { zoster or varicella, urinary tract infection, } \\
\text { alopecia, irregular menstruation }\end{array}$ \\
\hline 7 & $\begin{array}{l}\text { Randomized clinical } \\
\text { trial }\end{array}$ & $\begin{array}{l}\mathrm{TAC}+\mathrm{MMF}+\mathrm{GC} \\
\text { vs } \mathrm{CYC}+\mathrm{GC}\end{array}$ & $\begin{array}{l}\text { M: TAC (3-4mg/day), maintain a blood concentration within } 10 \\
\mathrm{ng} / \mathrm{mL}, \mathrm{MMF}(0.75-1 \mathrm{~g} / \text { day), maintain AUC from } 0 \text { to } 12 \mathrm{~h} \text { of } \\
\text { MPA within } 45 \mathrm{mg} \mathrm{h} / \mathrm{L} \text {. C: IVC } 0.5-1 \mathrm{~g} / \mathrm{m}^{2} \text { monthly for } 6 \text { months. } \\
\text { All patients received MP pulse therapy }\end{array}$ & $\begin{array}{l}\text { 18-60 yr biopsy-proven LN } \\
\text { diagnosed within } 6 \text { months; } \\
\text { had a diagnosis of class III, } \\
\text { IV, V, III+V, and IV+V LN }\end{array}$ & $\begin{array}{l}\text { CR, TR, proteinuria levels, } \\
\text { albumin, SLE-DAI, negative rate of } \\
\text { ds-DNA }\end{array}$ & $\begin{array}{l}\text { Cytomegalovirus infection, fungal infection, } \\
\text { bacterial infection, skin infection, lung } \\
\text { infection, gastrointestinal symptoms, urinary } \\
\text { system infection, leukopenia }\end{array}$ \\
\hline 11 & $\begin{array}{l}\text { Randomized clinical } \\
\text { trial }\end{array}$ & $\begin{array}{l}\mathrm{TAC}+\mathrm{MMF}+\mathrm{GC} \\
\text { vs } \mathrm{CYC}+\mathrm{GC}\end{array}$ & $\begin{array}{l}\text { M: TAC (2-4mg/day), MMF ( } 0.5-1 \mathrm{~g} / \text { day). C: IVC } 8-12 \mathrm{mg} / \mathrm{kg} \\
\text { per month for } 24 \text { weeks. All patients received MP pulse therapy } \\
\text { followed by oral prednisone }\end{array}$ & $\begin{array}{l}\text { Biopsy-proven LN had a } \\
\text { diagnosis of class IV LN }\end{array}$ & $\mathrm{CR}, \mathrm{TR}$ & Hypertension \\
\hline 9 & $\begin{array}{l}\text { Randomized clinical } \\
\text { trial }\end{array}$ & $\begin{array}{l}\mathrm{TAC}+\mathrm{MMF}+\mathrm{GC} \\
\text { vs } \mathrm{CYC}+\mathrm{GC}\end{array}$ & $\begin{array}{l}\text { M: TAC } 4 \mathrm{mg} / \text { day, MMF } 1 \mathrm{~g} / \text { day. C: IVC } 0.75 \mathrm{~g} / \mathrm{m}^{2} \text { to maximum } \\
\text { of less than } 1.2 \mathrm{~g} \text { per month for } 6-9 \text { months. All received MP pulse } \\
\text { therapy followed by oral prednisone }\end{array}$ & $\begin{array}{l}\text { Biopsy-proven LN had a } \\
\text { diagnosis of class IV, } \\
\text { III+V, and IV+V LN }\end{array}$ & $\mathrm{CR}, \mathrm{TR}$ & $\begin{array}{l}\text { Gastrointestinal syndrome, leucopenia, } \\
\text { hypertension, herpes zoster or varicella, } \\
\text { irregular menstruation, adverse reaction rate }\end{array}$ \\
\hline 6 & $\begin{array}{l}\text { Randomized clinical } \\
\text { trial }\end{array}$ & $\begin{array}{l}\mathrm{TAC}+\mathrm{MMF}+\mathrm{GC} \\
\text { vs } \mathrm{CYC}+\mathrm{GC}\end{array}$ & $\begin{array}{l}\text { M: TAC } 4 \mathrm{mg} / \text { day, blood concentration within 4-7 } \mathrm{ng} / \mathrm{mL}, \mathrm{MMF} \\
1 \mathrm{~g} / \text { day; AUC from } 0 \text { to } 12 \mathrm{~h} \text { of MPA at } 20-30 \mathrm{mg} \mathrm{h} / \mathrm{L} \text {. C: IVC } 0.5- \\
1 \mathrm{~g} / \mathrm{m} 2 \text { monthly for } 6-9 \text { months. All received MP pulse therapy } \\
\text { followed by oral prednisone }\end{array}$ & $\begin{array}{l}\text { Biopsy-proven LN had a } \\
\text { diagnosis of class IV, } \\
\text { III+V, and IV+V LN }\end{array}$ & $\mathrm{CR}, \mathrm{TR}$ & $\begin{array}{l}\text { Gastrointestinal syndrome, leucopenia, } \\
\text { hypertension, hyperglycemia, Pneumonia, } \\
\text { herpes zoster or varicella, skin infection, } \\
\text { irregular menstruation, adverse reaction rate }\end{array}$ \\
\hline
\end{tabular}


J Pharm Pharm Sci (www.cspsCanada.org) 22, 365 - 375, 2019

\begin{tabular}{|c|c|c|c|c|c|c|c|}
\hline 12 & $\begin{array}{l}\text { Randomized } \\
\text { trial }\end{array}$ & clinical & $\begin{array}{l}\mathrm{TAC}+\mathrm{MMF}+\mathrm{GC} \\
\text { vs } \mathrm{CYC}+\mathrm{GC}\end{array}$ & $\begin{array}{l}\text { M: TAC } 0.15 \mathrm{mg} / \mathrm{kg} \text { daily, MMF } 50 \mathrm{mg} / \mathrm{kg} \text { daily. C: IVC } 0.8-1 \mathrm{~g} \\
\text { monthly for } 9 \text { months. All received MP pulse therapy followed by } \\
\text { oral prednisone }\end{array}$ & $\begin{array}{l}\text { Biopsy-proven LN had a } \\
\text { diagnosis of class II, III, } \\
\text { IV, III+V, and IV+V LN }\end{array}$ & $\begin{array}{l}\mathrm{CR}, \mathrm{TR} \text {, negative rate of ds-DNA, } \\
\text { negative rate of ANA, proteinuria } \\
\text { levels, albumin, SLE-DAI }\end{array}$ & $\begin{array}{l}\text { Gastrointestinal syndrome, leucopenia, } \\
\text { alopecia, irregular menstruation }\end{array}$ \\
\hline 8 & $\begin{array}{l}\text { Randomized } \\
\text { trial }\end{array}$ & clinical & $\begin{array}{l}\mathrm{TAC}+\mathrm{MMF}+\mathrm{GC} \\
\text { vs } \mathrm{CYC}+\mathrm{GC}\end{array}$ & $\begin{array}{l}\text { M: TAC (3-4mg/day); blood concentration within } 10 \mathrm{ng} / \mathrm{mL} \text {, } \\
\text { MMF (0.75-1 g/day), maintain AUC(0-12h) of MPA within } 45 \mathrm{mg} \\
\text { h/L. C: IVC } 0.5-1 \mathrm{~g} / \mathrm{m}^{2} \text { monthly for } 6 \text { months. All received MP } \\
\text { pulse therapy followed by oral prednisone }\end{array}$ & $\begin{array}{l}\text { Biopsy-proven LN had a } \\
\text { diagnosis of class III, IV, V } \\
\text { LN }\end{array}$ & $\begin{array}{l}\mathrm{CR} \text {, TR, negative rate of ds-DNA, } \\
\text { negative rate of ANA, proteinuria } \\
\text { levels, albumin, SLE-DAI }\end{array}$ & $\begin{array}{l}\text { Gastrointestinal syndrome, leucopenia, } \\
\text { alopecia }\end{array}$ \\
\hline 13 & $\begin{array}{l}\text { Randomized } \\
\text { trial }\end{array}$ & clinical & $\begin{array}{l}\text { LEF+MMF vs } \\
\text { CYC }\end{array}$ & $\begin{array}{l}\text { M: LEF } 20 \mathrm{mg} / \text { day for } 3 \text { months, stepping by LEF } 10 \mathrm{mg} / \text { day for } 6 \\
\text { months; at the same time, MMF } 250 \mathrm{mg} \text { bid for } 9 \text { months. C: IVC } \\
0.8-1.0 \mathrm{~g} 2 \text { times / month, } 2 \text { months later } 1 \text { time / month for } 9 \\
\text { months }\end{array}$ & $\begin{array}{l}\text { Biopsy-proven LN had a } \\
\text { diagnosis of class II, III, } \\
\text { IV, III+V, and IV+V LN }\end{array}$ & $\begin{array}{l}\mathrm{CR}, \mathrm{TR} \text {, negative rate of ds-DNA, } \\
\text { negative rate of ANA, proteinuria } \\
\text { levels, albumin, SLE-DAI }\end{array}$ & $\begin{array}{l}\text { Gastrointestinal syndrome, leucopenia, skin } \\
\text { infection, irregular menstruation, adverse } \\
\text { reaction rate }\end{array}$ \\
\hline 14 & $\begin{array}{l}\text { Randomized } \\
\text { trial }\end{array}$ & & $\begin{array}{l}\mathrm{LEF}+\mathrm{MMF}+\mathrm{GC} \\
\text { vs } \mathrm{CYC}+\mathrm{GC}\end{array}$ & $\begin{array}{l}\text { M: LEF } 20 \mathrm{mg} / \text { day for } 3 \text { months, LEF } 10 \mathrm{mg} / \mathrm{day} \text { for } 6 \text { months; at } \\
\text { the same time, MMF } 250 \mathrm{mg} \text { bid for } 9 \text { months. Furthermore, At } \\
\text { the same time oral prednisone }(0.8-1.0 \mathrm{mg} / \mathrm{kg} \text {, gradually reduced } \\
\text { to } 6-10 \mathrm{mg} \text { / day after } 6 \text { weeks). C: IVC } 0.8-1.0 \mathrm{~g} \text { once/month for } \\
9 \text { months. All received oral prednisone }\end{array}$ & NS & $\begin{array}{l}\text { CR, TR, negative rate of ds-DNA, } \\
\text { negative rate of ANA, proteinuria } \\
\text { levels, albumin, SLE-DAI }\end{array}$ & $\begin{array}{l}\text { Gastrointestinal syndrome, leucopenia, } \\
\text { alopecia, irregular menstruation, adverse } \\
\text { reaction rate }\end{array}$ \\
\hline 15 & $\begin{array}{l}\text { Randomized } \\
\text { trial }\end{array}$ & clinical & $\begin{array}{l}\mathrm{LEF}+\mathrm{MMF}+\mathrm{GC} \\
\text { vs } \mathrm{CYC}+\mathrm{GC}\end{array}$ & $\begin{array}{l}\text { M: combining LEF } 10 \mathrm{mg} \text { qd and MMF } 1 \mathrm{~g} \text { qd for } 6 \text { months. C: } \\
\text { IVC } 0.5-1.0 \mathrm{~g} / \mathrm{m}^{2} \text { once } / \text { month for } 6 \text { months. All the patients from } \\
\text { two groups were treated with GC. MP } 500 \mathrm{mg} / \text { day for } 3 \text { days }+\end{array}$ & $\begin{array}{l}\text { Biopsy-proven LN had a } \\
\text { diagnosis of class II, III, } \\
\text { IV, III+V, and IV+V LN }\end{array}$ & $\begin{array}{l}\text { CR, TR, negative rate of ds-DNA, } \\
\text { negative rate of ANA, proteinuria } \\
\text { levels, SLE-DAI }\end{array}$ & $\begin{array}{l}\text { Gastrointestinal syndrome, upper respiratory } \\
\text { infection, herpes zoster or varicella, irregular } \\
\text { menstruation, adverse reaction rate }\end{array}$ \\
\hline
\end{tabular}


J Pharm Pharm Sci (www.cspsCanada.org) 22, 365 - 375, 2019

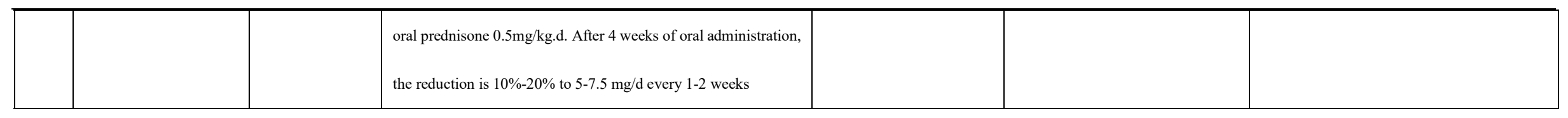

Abbreviations: TAC: tacrolimus; GC: glucocorticoids; CYC: cyclophosphamide; LEF: leflunomide; MMF: mycophenolate mofetil; MP: methylprednisolone; AUC: area under the curve; MPA:

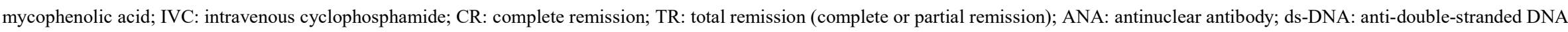

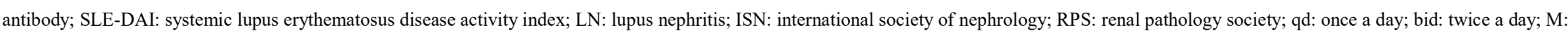

multitarget therapy group; C: control group; NS: Not shown. 
Table 2. Meta-analysis of the efficacy of multitarget therapy in induction therapy of patients with lupus nephritis

\begin{tabular}{|c|c|c|c|c|c|c|}
\hline Therapeutic regimen & Indicators & $\begin{array}{l}\text { Studies } \\
\text { Number }\end{array}$ & $\begin{array}{l}\mathrm{Q} \text { test } \\
P \text {-value }\end{array}$ & $\begin{array}{l}\text { Model } \\
\text { selected }\end{array}$ & $\begin{array}{l}\text { OR/WMD } \\
(95 \% \mathrm{CI})\end{array}$ & $\mathrm{P}$ \\
\hline \multirow[t]{8}{*}{ Multitarget Therapy $+\mathrm{GC}$ vs. $\mathrm{CYC}+\mathrm{GC}$} & $\mathrm{CR}$ & 11 & 0.57 & Fixed & $3.06(2.35,3.99)$ & $<0.00001$ \\
\hline & TR & 11 & 0.58 & Fixed & $3.83(2.77,5.31)$ & $<0.00001$ \\
\hline & Proteinuria levels & 5 & 0.008 & Random & $-0.55(-0.79,-0.30)$ & $<0.0001$ \\
\hline & Albumin & 4 & 0.0002 & Random & $3.50(1.04,5.95)$ & 0.005 \\
\hline & Albumin rise level & 2 & 0.25 & Fixed & $1.96(0.63,3.29)$ & 0.004 \\
\hline & Negative rate of ds-DNA & 6 & 0.61 & Fixed & $2.13(1.51,3.01)$ & $<0.0001$ \\
\hline & Negative rate of ANA & 4 & 0.69 & Fixed & $2.82(1.77,4.50)$ & $<0.0001$ \\
\hline & SLE-DAI & 5 & 0.0001 & Random & $-1.80(-2.78,-0.81)$ & 0.0004 \\
\hline \multirow[t]{8}{*}{$\mathrm{TAC}+\mathrm{MMF}+\mathrm{GC}$ vs. $\mathrm{CYC}+\mathrm{GC}$} & $\mathrm{CR}$ & 8 & 0.31 & Fixed & $3.10(2.30,4.19)$ & $<0.00001$ \\
\hline & $\mathrm{TR}$ & 8 & 0.46 & Fixed & $4.06(2.80,5.89)$ & $<0.00001$ \\
\hline & Proteinuria levels & 2 & 0.37 & Fixed & $-0.61(-0.76,-0.45)$ & $<0.00001$ \\
\hline & Albumin & 2 & 0.65 & Fixed & $5.21(3.44,6.98)$ & $<0.00001$ \\
\hline & Albumin rise level & 2 & 0.25 & Fixed & $1.96(0.63,3.29)$ & 0.004 \\
\hline & Negative rate of ds-DNA & 4 & 0.35 & Fixed & $2.09(1.39,3.15)$ & 0.0004 \\
\hline & Negative rate of ANA & 2 & 0.43 & Fixed & $3.40(1.72,6.74)$ & 0.0005 \\
\hline & SLE-DAI & 2 & 0.71 & Fixed & $-1.91(-2.51,-1.30)$ & $<0.00001$ \\
\hline \multirow[t]{7}{*}{$\mathrm{LEF}+\mathrm{MMF}+\mathrm{GC}$ vs $\mathrm{CYC}+\mathrm{GC}$} & $\mathrm{CR}$ & 3 & 0.89 & Fixed & $2.93(1.69,5.08)$ & 0.0001 \\
\hline & TR & 3 & 0.47 & Fixed & $3.16(1.60,6.23)$ & 0.0009 \\
\hline & Proteinuria levels & 3 & 0.04 & Random & $-0.48(-0.87,-0.09)$ & 0.02 \\
\hline & Albumin & 2 & 0.06 & Random & $1.87(-0.24,3.98)$ & 0.08 \\
\hline & Negative rate of ds-DNA & 2 & 0.62 & Fixed & $2.22(1.16,4.26)$ & 0.02 \\
\hline & Negative rate of ANA & 2 & 0.57 & Fixed & $2.39(1.26,4.53)$ & 0.007 \\
\hline & SLE-DAI & 3 & $<0.0001$ & Random & $-1.79(-3.64,0.07)$ & 0.06 \\
\hline
\end{tabular}

Abbreviations: TAC, tacrolimus; GC, glucocorticoids; MMF, mycophenolate mofetil; LEF: leflunomide; CYC, cyclophosphamide; CR, complete remission; TR, total remission, complete plus partial remission; SLE-DAI, systemic lupus erythematosus disease activity index; OR: odds ratio; WMD, weighted mean difference; CI: confidence intervals. 
J Pharm Pharm Sci (www.cspsCanada.org) 22, 365 - 375, 2019

Table 3. Meta-analysis of the safety of multitarget therapy in induction therapy of patients with lupus nephritis

\begin{tabular}{|c|c|c|c|c|c|}
\hline Indicators & $\begin{array}{l}\text { Studies } \\
\text { Number }\end{array}$ & $\begin{array}{l}\mathrm{Q} \text { test } \\
P \text {-value }\end{array}$ & $\begin{array}{l}\text { Model } \\
\text { selected }\end{array}$ & $\begin{array}{l}\text { OR } \\
(95 \% \mathrm{CI})\end{array}$ & $\mathrm{P}$ \\
\hline Gastrointestinal syndrome & 10 & 0.006 & Random & $0.35(0.15,0.80)$ & 0.01 \\
\hline Leucopenia & 9 & 0.40 & Fixed & $0.38(0.22,0.67)$ & 0.0009 \\
\hline Hypertension & 5 & 0.87 & Fixed & $3.34(1.44,7.75)$ & 0.005 \\
\hline Hyperglycemia & 3 & 0.54 & Fixed & $1.09(0.38,3.14)$ & 0.88 \\
\hline Skin infection & 3 & 0.87 & Fixed & $0.67(0.17,2.59)$ & 0.56 \\
\hline Upper respiratory infection & 3 & 0.16 & Fixed & $0.78(0.45,1.34)$ & 0.36 \\
\hline Pneumonia & 4 & 0.70 & Fixed & $1.65(0.71,3.84)$ & 0.25 \\
\hline Herpes zoster or varicella & 5 & 0.52 & Fixed & $1.71(0.79,3.72)$ & 0.17 \\
\hline Urinary tract infection & 3 & 0.92 & Fixed & $0.71(0.22,2.27)$ & 0.56 \\
\hline Alopecia & 6 & 0.81 & Fixed & $0.55(0.28,1.08)$ & 0.08 \\
\hline Irregular menstruation & 8 & 0.88 & Fixed & $0.42(0.22,0.81)$ & 0.01 \\
\hline Adverse reaction rate & 6 & 0.0001 & Random & $0.28(0.10,0.81)$ & 0.02 \\
\hline
\end{tabular}

Abbreviations: OR: odds ratio; CI: confidence intervals. 